L. Lao*, C. Ramshaw and H. Yeung

\title{
Process intensification: water electrolysis in a centrifugal acceleration field
}

Department of Offshore, Process and Energy Engineering, Cranfield University, Cranfield, Bedfordshire, MK43 OAL, UK

(*author for correspondence, Tel: +44 (0)1234 754696, Fax: +44 (0)1234 754685, e-mail:

l.lao@cranfield.ac.uk)

\begin{abstract}
Intensification of hydrogen production by carrying out water electrolysis in a centrifugal acceleration field has been demonstrated. A prototype single cell rotary water electrolyser was constructed and a number of design challenges with regard to the practical application were addressed. The rotary electrolyser was tested over a range of current density, centrifugal acceleration, electrolyte concentration, temperature and electrode geometry. The test results showed that at normal cell operating conditions (7.7 M KOH solution, $348 \mathrm{~K}$ ) much of the cell voltage benefits were achieved at an acceleration of about $16 \mathrm{~g}\left(\mathrm{~g}=9.81 \mathrm{~m} \mathrm{~s}^{-2}\right)$ equivalent to a rotational speed of $500 \mathrm{rpm}$ (revolution per minute) for the rotary cell. The rotary electrolyser cell voltage was about $0.25-0.5 \mathrm{~V}$ less than the equivalent static cell under similar operating conditions, depending on the current density. The cell voltages achieved, without an effective electrode catalytic coating, were comparable with typical industrial values of fully developed pressurised cells. At a higher acceleration of $41 \mathrm{~g}$, the rotary cell's current density can be up to $13.5 \mathrm{kA} \mathrm{m}^{-2}$ without causing gas bubble blinding of the membranes and electrodes. When comparing with typical current densities (about $5 \mathrm{kA} \mathrm{m}^{-2}$ ) found in commercial systems, this work demonstrated the potential of intensification.
\end{abstract}

\section{Key words}

centrifugal field, process intensification, water electrolysis, hydrogen production 


\section{Introduction}

Process intensification is a strategy for process plant construction which involves the development of equipment having volumes which are typically at least two orders of magnitude smaller than those of their conventional equivalents. The initial incentive for this approach was the reduction in plant system cost which may be achieved when lower installation costs attributable to pipe work, support structure and civil engineering items such as roads/foundations, are taken into account. Subsequently, it has been recognised that the other benefits of an intensified plant may be as important as its initial cost. For example, intrinsic safety is improved due to the dramatically decreased inventories of potentially hazardous process fluids. Also process response times are much shorter in intensified equipment leading to the feasibility of "just-in-time" manufacture of products (e.g. pharmaceuticals, fine chemicals, paints etc.) that would otherwise be made in batches, with all that implies in terms of warehouse and stock costs. Of greater interest in the context of the present work is the recognition that the thermodynamic efficiency of a given process is intimately linked to the irreversibilities incurred in transferring heat, mass and momentum within the key unit operations.

The practical application of process intensification depends on our ability to devise fluid dynamic environments which stimulate high transfer coefficients for heat and mass so that for a given set of intrinsic chemical kinetics, they do not limit the overall system output. Among a variety of methods to facilitate the heat mass and momentum transfers, the centrifugal field method perhaps is the most widely applied technique to processes involving two phases, e.g. absorption, distillation, extraction and phase separation[1-10]. Generally speaking the attainment of high transfer coefficients allows us to reduce temperature and concentration differentials and, thus, thermodynamic irreversibilities. In an electrolytic operation this can result in a substantial reduction in cell voltage particularly at high current densities as will be shown below.

In any multiphase system the fluid dynamic behaviour is largely dictated by the buoyancy force which is a function of the buoyancy term $\Delta \rho G$ where $\Delta \rho$ is the phase density difference and $G$ is the applied acceleration. At very low levels of gravity(acceleration), such as those encountered in free fall or in space vehicles, interfacial forces dominate system behaviour so that bubbles are large and phase slip velocities are low. This leads to a very poor heat and mass transfer environment. Some observations of water electrolysis have been made under these conditions by two Japanese groups, one working with a 700 meter drop tower [11], and the other [12] using an aircraft in a parabolic flight trajectory for $25 \mathrm{~s}$. Photographs of the operating electrodes are reproduced in Figure 1 where it can be seen that there are significant differences between the features of bubble formation around the electrode under the conditions of terrestrial gravity (Figure 1(a)) and microgravity (Figure 1(b)) [11]. It is evident that operation at these micro levels of gravity incurs several problems:

- Bubbles adhere to the electrode

- Bubbles adhere to the membrane

- High gas volume fractions build up in the electrolyte and impair its conductivity 
- Electrode spacing has to be increased so as to facilitate bubble removal

It will be recognised that all these factors adversely influence the cell voltage. The obvious expectation following the above observations is that the imposition of higher accelerations on a water electrolysis cell will effectively prevent bubble blinding of the membranes and electrodes ensuring a very low gas volume fraction in the electrolyte. The other effect is that the enhanced bubble buoyancy occurs exactly where it is needed to increase the electrode mass transfer coefficient, i.e. within the boundary layer. With bubble disengagement no longer a problem the electrodes can be brought closer together and possibly structured to give high surface area. This further reduces the cell resistance and the effective current density.

Gas disengagement in an electrolysis cell can be facilitated via forming shear flow on electrode surface by using a variety of methods, e.g. fluid rotation, oscillation and vibrations, in cell. For example, in a rotating electrolyser presented in a patent by Fleischmann et al [13], separated shear flows were formed on two discs rotating in a pool of electrolyte. No detailed performance information was included in the patent.

As far as it can be ascertained, the idea of exploiting centrifugal acceleration fields for facilitating gas disengagement was first proposed for water electrolysis in a very brief patent by Thomson in 1929 [14]. This document presented a simple sketch but gave no performance details. Much later a patent by Hoover [15] described a rotating chlor-alkali cell, however there were also no performance details revealed. The concept was further extended by Ramshaw [1] who also used a chlor-alkali cell with a Nafion membrane. The rotating unit ( $1 \mathrm{~m}$ long by $0.5 \mathrm{~m}$ diameter) comprised a $20 \%$ segment of two opposing spinning disc planar electrodes which were coated with an appropriate electro-catalysis. Bearing in mind that the standard ICI FM21 cell voltage when operating at $3.0 \mathrm{kA} \mathrm{m}^{-2}$ was $3.17 \mathrm{~V}$, it was found that the rotating unit when operated at accelerations up to $200 \mathrm{~g}$ (about $900 \mathrm{rpm}$ ) gave very significant energy savings. There appeared to be little point in exceeding this level of acceleration for that particular cell configuration. At $5.0 \mathrm{kA} \mathrm{m}^{-2}$ the voltage reductions were even greater. The author noted that with conventional lubrication, the energy needed to maintain the cell rotation at the modest speeds is small compared with the large energy saving to be made in a realistic industrial application.

In 2002 Cheng et al. [16] investigated chlor-alkali electrolysis in a conventional laboratory centrifuge using acidified brine and at temperatures up to $353 \mathrm{~K}$. The relationship between cell performance and the relative acceleration was evaluated using electrodes which comprised $\mathrm{RuO}_{2}-\mathrm{TiO}_{2} / \mathrm{Ti}$ mesh and $\mathrm{Pt} / \mathrm{Ti}$ mesh. Once again, very significant cell voltage reductions were generated when accelerations up to 190 $\boldsymbol{g}$ were applied. For example a reduction of $0.6 \mathrm{~V}$ was observed at a current density of $6.0 \mathrm{kA} \mathrm{m}^{-2}$. In addition the electrode mass transfer coefficient increased from $1.28 \times 10^{-5} \mathrm{~m} \mathrm{~s}^{-1}$ to $3.89 \times 10^{-4} \mathrm{~m} \mathrm{~s}^{-1}$. This feature is expected to improve the current efficiency for chlorine production.

Cheng et al. [17] also investigated water electrolysis with brine in the laboratory centrifuge. Once again it was demonstrated that centrifugal fields provided a powerful means for improving the electrolytic process, especially when nickel foam electrodes were used with concentrated potassium hydroxide solutions at $353 \mathrm{~K}$. Cell voltage reductions in an un-optimised cell arrangement varied from $0.36 \mathrm{~V}$ at $3.0 \mathrm{kA} \mathrm{m}^{-2}$ current density. 
From the above studies, it is clear that there is a significant body of evidence confirming that the application of enhanced acceleration to an electrolysis operation can result in major improvement to its energy efficiency. However, the experimental set up was not representative of industrial scale devices. The electrodes were immersed in a pool of electrolyte and rotating together inside a centrifuge. There was no consideration of many practical issues such as how to replenish electrolyte in the cell nor how to introduce a large electric current into to the rotating electrodes, etc. The tests were also limited, for example, the effect of electrode structure was not reported. The current densities used in tests were less than $6.0 \mathrm{kA} \mathrm{m}^{-2}$. There was also a lack of detailed information about the power consumption and energy efficiency of the cell.

The work reported in this paper is intended to address some of the practical issues of designing an industrial scale rotating electrolyser. A single cell rotating electrolyser was constructed to examine the effects of applied acceleration, structure of electrodes and electrolyte concentration on performance.

\section{Experimental setup}

The present study used a preliminary prototype configuration which can be loosely described as a single $0.2 \mathrm{~m}$ diameter spinning disc cell with a capability of running at up to $1,000 \mathrm{rpm}$ at a current density of up to $20 \mathrm{kA} \mathrm{m}^{-2}$. (In this paper a current density is defined in terms of electrolysis current and projected area of the electrodes, unless specified otherwise). The general arrangement is presented in Figure 2 where it can be seen that the cell is held on a hollow shaft which is supported between two pillow block bearings. Current is transmitted to the cell from one end of the shaft to the other via two rotary mercury-based encapsulated connectors.

During the process of configuring the experimental prototype the following issues, which were expected to be important for industrial application, were addressed.

\subsection{Current supply to the rotary cell}

Considerable thought has been given to the question of current supply to the rotating cell as the envisaged current level at industrial scale is expected to be at least 1,000 A for $0.5 \mathrm{~m}$ diameter cells in a bi-polar array. Several connection arrangements, e.g. slip ring assemblies, molten metal baths and mercury-based encapsulated connectors were considered and carefully appraised. The last two schemes were studied extensively.

For the molten metal bath trial, Cerrobend ${ }^{\mathrm{TM}}$ was identified as the alloy of choice as its melting point was approximately $343 \mathrm{~K}$ and has relatively low content of toxic cadmium. It appeared to be capable of coping with high currents while operating with low mechanical drag and low voltage drop. The experimental arrangement comprised of a disc which was attached to the shaft. The disc was partially immersed in a narrow bath of molten alloy. The alloy was heated to a controlled target temperature by immersed cartridge heaters and the system was shrouded by a cover plate to retain any liquid alloy spray. Early results were encouraging with voltage losses less than $0.1 \mathrm{~V}$ at currents of $100 \mathrm{~A}$. 
Unfortunately, after several hours of operation at temperatures around $353 \mathrm{~K}$, the alloy melt developed a mousse-like consistency which ultimately caused the bath contents to overflow. Despite exhaustive enquiries and investigation, no means could be found to avoid this problem and so the molten alloy experiments were suspended.

The trial of mercury-based encapsulated connector was then carried out using a commercially available product from Nova Ltd. The unit was capable of transmitting up to $250 \mathrm{~A}$ at speeds up to $1200 \mathrm{rpm}$ and generated very little mechanical drag. It retained the mercury in a hermetically sealed cylinder and did not therefore present a safety problem. The dimensions of the connector cylinder are $31 \mathrm{~mm}$ in diameter by $28 \mathrm{~mm}$ in length. These units were installed at each end of the shaft and have operated very effectively and reliably. Tests showed that the voltage drop across the connector at a current of $200 \mathrm{~A}$ and a rotation speed of $800 \mathrm{rpm}$ was about $0.06 \mathrm{~V}$ The heat generated from the connectors was moderate and the temperature rise during tests was very limited. More importantly, a $100 \mathrm{~mm}$ diameter connector should be able of dealing with a current of $1000 \mathrm{~A}$-- a reasonable industrial scale.

\subsection{Rotary electrolysis cell design}

The cell is shown in detail in Figure 3. It is symmetrical about its mid plane, which corresponds to the porous polypropylene membrane used to separate the anode and cathode compartments. The membrane was grafted polypropylene meltblown TR0950DG1 (0.125 $\mathrm{mm}$ thick) which was provided by Hollingsworth \& Vose Co. It allows free passage of the alkaline electrolyte while keeping the hydrogen and oxygen gas bubbles separate. The gas bubbles rise inwards to the hollow machine shaft where they are allowed to mix before leaving via the end of the shaft. It must be emphasised that this arrangement is only a temporary expedient for simplicity in this laboratory rotary cell, recognising that at the modest gas productions involved here, the hazard represented by the flammable gas mixture is unlikely to be significant. This approach is clearly unacceptable for a full scale unit. However it should be relatively simple to 'compartmentalise' the shaft to provide separate paths for the hydrogen and oxygen.

If the full disc area were to be electrochemically activated then the total current demand would be up to $600 \mathrm{~A}$ - a level that was deemed to be too high for the rotary connectors ultimately employed in this laboratory study. In view of this, most of the cell projected area was rendered inactive by incorporating a non conducting blank sheet which left two $45^{\circ}$ sectors active as shown in Figure 4 . The projected area of each sector was $11 \mathrm{~cm}^{2}$ thus the total projected area was $22 \mathrm{~cm}^{2}$. The current was supplied to and removed from the electrodes by a current feeder made of stainless steel sheet which was in direct contact with the electrodes. A gap (which was adjustable by using the blank sheets of different thickness) to facilitate gas disengagement was provided between the electrode and the polypropylene membrane by a non-conducting spacer sheet as shown. At the cell periphery the electrolyte solution flows through a set of holes from the feeder channel to the removal channel via the anode and the cathode compartments. When operating, the feeder channel contained an annular pool of electrolyte solution which was continuously fed via a stationary tube near the machine shaft. With the assistance from a peristaltic abstraction pump, the electrolyte was fed at flow rates of around $2.0 \times 10^{-4} \mathrm{~kg} \mathrm{~s}^{-1}$. The electrolyte, having passed through the cell, entered the removal channel which contained another 
annular pool of electrolyte with its inner radius dictated by the position of the stationary abstractor tube. It was expected that with continuous electrolyte replenishment and efficient gas disengagement, the electrolyte properties, e.g. concentration and temperature, were kept reasonably stable in the cell.

The electrodes (both anode and cathode) were made from nickel mesh comprising $0.224 \mathrm{~mm}$ diameter wire and with 40 meshes per inch. This gives a surface area to projected area ratio of 2.22 for each mesh. An image of the material is shown in Figure 4.

The rotary electrolyser was set up in an enclosure, in order to prevent the potential spillage of electrolyte solution from the cell. In addition, the temperature of the enclosure and hence the rig could be raised above the ambient temperature, by using a hot air blower.

\subsection{Instrumentation for the rotary cell}

It was essential that the rig should include means of data acquisition to abstract the operating data from the rotating system. The key data required were the anode/cathode voltage drop across the cell terminals and the electrolyte solution temperature which was measured by a thermocouple. The thermocouple sensing junction was submerged in the solution in removal annular pool of the cell. This information could be transmitted via a light multi-channel slip ring assembly. However, it was known that such a system could corrupt voltage signals due to the frictional heating of the tracks in combination with the Peltier effect. Accordingly, it was decided to use a digital telemetry system which was provided by Astech Ltd. This was capable of measuring voltage signals with resolutions of \pm 2.5 $\mathrm{mV}$. The telemetry system proved to be very satisfactory. For electrolyte solution temperature measurement the uncertainty was about $\pm 1.0 \mathrm{~K}$.

The power supply for the electrolyser was an HP/Agilent 6671A. It is able to deliver a very stable and precise current up to $220 \mathrm{~A}$ or a voltage up to $8 \mathrm{~V}$. The power supply was calibrated before it was put in use. This power supply was also used for the tests of a static electrolysis cell specified below.

\subsection{Static electrolysis cell}

In order to provide a comparison with conventional technology, a set of preliminary tests was also performed in a static cell which operated under similar conditions to those used for the rotary cell. A schematic of the static rig is showed in Figure 5. Electric current was supplied to the electrolyser sitting in a water bath. The electrolysis cell comprised of an anode, a cathode and an isolation membrane in between. The electrode dimension is $5.0 \mathrm{~cm}$ by $5.0 \mathrm{~cm}$, however some portion of the electrodes could be blocked off using an insulation film if a smaller active area was needed. The isolation membrane was used to separate the oxygen and hydrogen produced, simulating its counterpart of industrial water electrolysers. The membrane material used was that used in the rotary electrolyser described above. The inter-electrode gap of the cell could be adjusted using spacers of different thickness. Meanwhile different geometries of spacer designs could also provide different geometries of electrolyser cells. The preliminary investigations included the effects on the cell voltage due to electrode material and 
structure, electrolyte concentration and temperature. Obviously, the static cell was subjected to terrestrial gravity.

Although the static cell was very different from the rotary cell in geometrical configurations and electrolyte circulation arrangement, and therefore unable to provide a perfect comparison with the rotary cell, it was considered to be a useful reference case for the investigation of the effect of centrifugal field on gas disengagement.

\section{Experiment Results}

A large number of tests were performed for both the static and rotary cells at a range of current density, centrifugal acceleration, electrolyte concentration, and electrode geometry. During each test, fresh electrolyte solution was continuously replenished into the cell. Cell voltage and bulk temperature of the electrolyte were continuously recorded at a sample rate of $20 \mathrm{~Hz}$. With this sample rate we were able to record not only the stationary component of these parameters, but also variations caused by inter-electrode gas movement. The latter proved valuable for interpreting the performance of gas disengagement in the cell. The cell voltage was simultaneously logged with the bulk temperature. This enabled the effect of temperature on cell voltage to be studied.

\subsection{Preliminary tests performed using the static cell}

\subsubsection{Effect of electrode structure}

A major influence of electrode structure on cell voltage was observed in tests performed with the static cell. Figure 6 shows cell voltage data obtained for two different designs, namely, nickel mesh upon the stainless steel current feeding plate, and the stainless steel current feeding plate only. The conditions for the experiment were as follows: electrolyte, 7.7 M KOH solution; inter-electrode spacing $2.0 \mathrm{~mm}$. As can be seen in Figure 6, at a solution bulk temperature $348 \mathrm{~K}$, with a current density of less than 10 $\mathrm{kA} \mathrm{m}^{-2}$ there were no significant differences among cell voltages for the two electrode structures. However notable differences were observed when the current density was higher than $10 \mathrm{kA} \mathrm{m}^{-2}$. This behaviour is presumed to be due to a) the different electrolytic kinetics with different materials and $b$ ) the nickel mesh gave extra active electrode surface thereby enhancing the performance. These factors become much more critical for reducing the cell voltage at a high current density.

Further tests were carried out on the effect of extra activated area. Figure 7 shows data obtained with electrodes comprised of different number of nickel mesh layers. The electrolyte used was 7.7 M KOH at a bulk temperature of $348 \mathrm{~K}$. The inter-electrode spacing was $2.0 \mathrm{~mm}$. The cell voltage tended to reduce with the increase in the number of mesh layers at a fixed current density over the whole range of the current density tested. The benefit in cell voltage reduction with multiple mesh layers was most marked at high current density. This result again suggests that using an electrode with a high surfaceto-volume ratio helps in reducing the cell voltage and thus improves energy efficiency in water electrolysis. 
Test results with the static cell also showed that the cell voltage was significantly affected by the interelectrode spacing, particularly at high current densities. Figure 8 shows the cell voltage traces obtained from the cell inter-electrode spacings of $1.0 \mathrm{~mm}$ and $3.0 \mathrm{~mm}$ and the electrode used comprised of one layer of nickel mesh upon the stainless steel current feeding plate. Again the electrolyte used was 7.7 M $\mathrm{KOH}$ at a bulk temperature of $348 \mathrm{~K}$. It shows that for a fairly high current density (10 kA m $)$, electrode spacing has a strong influence on the cell voltage behaviour. Not only the cell voltage with a larger gap is reduced, it also shows much less variability. Presumably this was due to easier interelectrode gas bubble removal and lower inter electrode void fraction. This indicates that the conflict between gas disengagement and inter-electrode space is a fundamental problem in designing ultracompact static cells. One effective way of overcoming this problem is to exploit the benefits of intensified fluid dynamic behaviour achievable with enhanced centrifugal fields.

\subsubsection{Effect of electrolyte concentration}

Figure 9 shows cell voltage data obtained at different electrolyte concentrations, 2.0 M, 7.7 M and 11.9 $\mathrm{M} \mathrm{KOH}$. The electrodes were constructed with 3 layers of nickel mesh upon a stainless steel current feeding plate, with an inter-electrode gap of $2.0 \mathrm{~mm}$. The electrolyte solution bulk temperature was 348 $\mathrm{K}$. As can be seen, due to the increase in gas production, cell voltages for all three concentrations increased with the increase of current density, however major differences were observed between the cell voltages at the concentration of $2.0 \mathrm{M}$ and the others. Over the whole range of the current density tested, the cell voltage for the 2.0 M solution increased more sharply than for both the $7.7 \mathrm{M}$ and 11.9 $\mathrm{M}$ solutions, however there were no major differences in cell voltages at the concentration of $7.7 \mathrm{M}$ and $11.9 \mathrm{M}$.

These phenomena were likely because the resistivity of an electrolyte solution is related to its concentration. For a given electrolyte the resistivity of a solution would be inversely proportional to the mole concentration of the solution. Therefore the inter-electrode resistance of $2.0 \mathrm{M}$ electrolyte solution will be about 3 times higher than that of $7.7 \mathrm{M}$ solution. However in comparing with the resistivity of the $2.0 \mathrm{M}$ solution the resistivity difference between $7.7 \mathrm{M}$ solution and $11.9 \mathrm{M}$ solution would be small.

\subsection{Tests performed in the rotary cell}

\subsubsection{The effect of centrifugal acceleration}

Figure 10 shows the dependence of cell voltage on centrifugal acceleration obtained with the rotary cell. The electrodes were 3 layers of nickel mesh upon stainless steel current feeding plate with an inter-electrode gap of $1.0 \mathrm{~mm}$, operated at current densities from 2.3 to $22.5 \mathrm{kA} \mathrm{m}^{-2}$. The electrolyte used was a 7.7 M KOH solution at a bulk temperature of $344 \mathrm{~K}$. The value of the acceleration shown in the figure was a relative value which was calculated by centrifugal acceleration divided by the gravitational acceleration, i.e. $g=9.81 \mathrm{~m} \mathrm{~s}^{-2}$. As one can see, the benefit of the centrifugal acceleration on reducing cell voltages occurred over a fairly large range of the acceleration (over $60 \mathrm{~g}$, equivalent to 
a speed of $900 \mathrm{rpm}$ for the test rotary cell electrolyser). However the major benefit occurred in the lower acceleration range. For example at a current density of $13.5 \mathrm{kA} \mathrm{m}^{-2}$ over $80 \%$ of voltage reduction was achieved at an acceleration of about $16 \mathrm{~g}$, equivalent to a low rotational speed of 500 rpm of the rotary cell for all tested current densities. For the current density of $4.5 \mathrm{kA} \mathrm{m}^{-2}, 95 \%$ of voltage reduction was achieved at an acceleration of $16 \mathrm{~g}$. Also the higher the current density, the more was the influence of centrifugal acceleration. A similar tendency was also observed with electrodes with different nickel mesh layer numbers, geometries or materials, operated under similar conditions.

The above results are to be expected as the cell voltage in a water electrolysis system is strongly influenced by the inter-electrode gas removal rate. The electric resistive loss in a water electrolyser is mainly due to produced gas bubbles that a) blind electrode surfaces and b) reduce inter-electrode conductance with an increasing void fraction in the inter-electrode space. However both of these effects are favourably reduced at higher accelerations, particularly when high current densities are involved.

Similar to the static cell, the effects of centrifugal acceleration field on inter-electrode bubble disengagement can be observed by following the cell voltage traces. It was believed that the variability of the cell voltage reflects the inter-electrode gas/liquid flow regime. When the large gas bubbles congest and move in the inter-electrode space the flow would be very turbulent and chaotic. This would cause the fluctuations of the equivalent electric resistance of the fluids in the inter-electrode space, leading to a corresponding cell voltage change. However when the gas bubbles are small in size and the inter-electrode void fraction is low, the inter-electrode gas/liquid mixture would be homogeneous, therefore the inter-electrode resistivity would be stable and so would the cell voltage. Figure 11 shows cell voltage traces for the rotary cell operated at different current densities and centrifugal accelerations (top) and their positions on the plot of cell voltage against centrifugal acceleration (bottom). The electrodes comprised of 3 layers of nickel mesh upon a stainless steel current feeding plate with 1.0 $\mathrm{mm}$ inter-electrode spacing. Electrolyte used was a $7.7 \mathrm{M} \mathrm{KOH}$ solution at a bulk temperature of 344 $\mathrm{K}$. With a high current density of $13.5 \mathrm{kA} \mathrm{m}^{-2}$ and low acceleration of $3.2 \mathrm{~g}$ (i.e. trace (a) in the figure), the inter-electrode gas disengagement was poor, and the cell voltage trace shows large fluctuations with an average value of around $2.5 \mathrm{~V}$.

However, by either increasing the centrifugal acceleration to $41 \mathrm{~g}$ (trace (b) in the figure) or reducing the current density to $2.3 \mathrm{kA} \mathrm{m}^{-2}$ (trace (c) in the figure), voltage fluctuations were damped and levels were lowered, suggesting reduced gas volume fraction in the cell and improved inter-electrode gas disengagement. These results support the theory that the enhanced acceleration field facilitated gas bubble removal thus mitigating inter-electrode bubble congestion/blinding.

Of practical importance, the results showed that with an increased centrifugal acceleration of $41 \mathrm{~g}$ (equivalent to a rotational speed $800 \mathrm{rpm}$ of the rig), the gas disengagement between narrowly spaced electrodes was improved significantly even at a current density of $13.5 \mathrm{kA} \mathrm{m}^{-2}$, which is almost 3 times of the operation current density in typical commercial static electrolysers. This demonstrated a potential intensification of the electrolysis. 


\subsubsection{Effect of electrode activated area}

Figure 12 shows curves of cell voltage against centrifugal acceleration, with electrodes comprising of different number of layers of nickel mesh upon a stainless steel current feeding plate all with a $2.0 \mathrm{~mm}$ inter-electrode gap, operated at a fixed current density of $13.5 \mathrm{kA} \mathrm{m}^{-2}$ at ambient temperature (around $297 \mathrm{~K})$. The electrolyte was a solution of 7.7 M KOH. As with the static cell, extra layers of nickel mesh helped to reduce cell voltage. This was due to the increased effective activated electrode area. It is worth noting that similar results were obtained when operated at other current densities.

\subsubsection{Effect of electrolyte temperature and concentration}

Figure 13 shows curves of cell voltage against centrifugal acceleration for a fixed current density of $13.5 \mathrm{kA} \mathrm{m}^{-2}$, at different electrolyte bulk temperatures. The electrolyte used was a 7.7 M KOH solution. The electrode comprised of 3 layers of nickel mesh upon a stainless steel current feeding plate with a $2.0 \mathrm{~mm}$ inter-electrode gap. Similar to the static cell, a significant cell voltage reduction was observed in the rotary cell when the electrolyte temperature was raised from ambient (around $297 \mathrm{~K}$ ) to $354 \mathrm{~K}$. The test results at other fixed current densities showed a similar trend.

Figure 14 shows the influence of electrolyte concentration on cell voltage against centrifugal acceleration for a fixed current density of $22.5 \mathrm{kA} \mathrm{m}^{-2}$ at ambient temperature. The electrodes were 3 layers of nickel mesh upon a stainless steel current feeding plate with a $2.0 \mathrm{~mm}$ inter-electrode gap. Similar to the case for the static cell, significant cell voltage reductions were also observed for the rotary cell when the concentration of the $\mathrm{KOH}$ solution was increased from 2.0 M to 7.7 M. However there was little difference between the cell voltages at $\mathrm{KOH}$ concentrations of 7.7 $\mathrm{M}$ and 11.9 M. As explained in the results from the static cell tests, this could also be because of the large resistivity difference between 2.0 $\mathrm{M}$ solution and the other solutions, and a small resistivity difference between 7.7 $\mathrm{M}$ and $11.9 \mathrm{M}$ solutions. It is worth noting that at $2.0 \mathrm{M} \mathrm{KOH}$ and a low centrifugal acceleration field, the cell voltage was so high that it was out of the measuring range of the instruments.

\subsubsection{Energy conversion efficiency of the rotary electrolyser}

In order to calculate the efficiency of the electrolysis process, the theoretical energy needed is divided by the actual energy used by the electrolysis unit to create hydrogen.

The reaction of the formation of water is:

$$
\mathrm{H}_{2}+1 / 2 \mathrm{O}_{2} \rightarrow \mathrm{H}_{2} \mathrm{O}+\text { energy }
$$

At $298 \mathrm{~K}$ and $100 \mathrm{kPa}$, the heat of formation of liquid water, or the energy released when water is formed in the reaction above is $39 \mathrm{~kW} \mathrm{~h} \mathrm{~kg}^{-1}$ of hydrogen. This value is the higher heating value (HHV) of hydrogen.

The electrolysis reaction is the opposite of the formation of water reaction:

$$
\mathrm{H}_{2} \mathrm{O}+\text { energy } \rightarrow \mathrm{H}_{2}+1 / 2 \mathrm{O}_{2}
$$


The theoretical amount of energy needed to create hydrogen from water using electrolysis is $39.0 \mathrm{kWh}$ $\mathrm{kg}^{-1}$.

For the rotary electrolyser (electrodes: 3 layers of nickel mesh upon a stainless steel current feeding plate; $1.0 \mathrm{~mm}$ inter-electrode space; electrolyte: $7.7 \mathrm{M} \mathrm{KOH}$ solution, bulk temperature $344 \mathrm{~K}$. c.f. Figure 10), the cell voltage was $2.01 \mathrm{~V}$ for a centrifugal acceleration of $41 \mathrm{~g}$ (corresponding to 800 $\mathrm{rpm}$ ) and a current density of $4.5 \mathrm{kA} \mathrm{m}^{-2}$. This corresponds to $53.2 \mathrm{kWh} \mathrm{kg}^{-1}$ required for hydrogen production. Thus the energy efficiency of the electrolyser was $73 \%$. It is worth noting that in this calculation the energy for driving the rotary cell and feeding electrolyte have not been included, though they were expected to be small in comparison with the energy consumption for electrolysis. Nonetheless even with this crudely designed rotary electrolyser, which was far from optimised, the energy efficiency is comparable to those of pressurised commercial water electrolysis systems, which typically range up to $73 \%$ [18].

\section{Discussions}

The current density tested with the experimental rotary electrolyser was up to $22.5 \mathrm{kA} \mathrm{m}^{-2}$, based on projected electrode area. At a centrifugal acceleration of $41 \mathrm{~g}$, the electrolyser can be operated at a current density of $13.5 \mathrm{kA} \mathrm{m}^{-2}$ without causing bubble congestion in the $1.0 \mathrm{~mm}$ inter-electrode space, as the gas disengagement is facilitated by the centrifugal field. This current density is much higher than the current density of $4.5 \mathrm{kA} \mathrm{m}^{-2}$, a typical value for conventional optimized electrolysers. The width of the electrolyser cell was about $5.0 \mathrm{~mm}$ for three layers of nickel mesh. For a 10 cell stacked unit, the active length is only $50 \mathrm{~mm}$. With further development, very high power density could be possible by utilizing the benefit of high applied accelerations.

It was noted that with the prototype rotary electrolyser, over $80 \%$ of the cell voltage reductions at different current density were achieved when the centrifugal acceleration reached around $16 \mathrm{~g}$ (at 500 $\mathrm{rpm}$ ). This value is much less than that reported by Ramshaw [1], which showed that for a differently designed brine rotary electrolyser, accelerations in the region of 100-200 $g$ were needed in order to approach its asymptotic voltage. This difference may suggest that the acceleration needed for a rotary electrolyser to reach its asymptotic cell voltage is very dependent on its design. Thus when a cell design involves electrodes having a large current density, leading to bubble congestion, it is to be expected that the voltage performance will be more sensitive to the applied acceleration.

In a larger rotor, multiple layers of fine mesh in direct contact with the membrane and current feeder may therefore require a higher acceleration to achieve the optimum operating voltage. Higher accelerations allow the capacity of a fully optimised cell configuration to be exploited. A pressurised prototype with a more sophisticated electrode design is expected to be more energy efficient and have a significantly higher operating intensity than existing industrial units.

The cell voltage trace showed that both average and fluctuating values increases with inefficient gas disengagement in the cell. This was because that the conductivity of the inter-electrode gas/liquid mixture was reduced and disturbed by bubble congestion. The voltage trace became very calm as the 
gas disengagement was improved at an increased rotational speed. In a practical application, this behavior could be of important interests for the system optimization. The cell voltage can be used to monitor the gas disengagement of a rotary cell and to ensure optimal performance of the system is achieved.

\section{CONCLUSIONS}

To establish the feasibility and performance of intensified hydrogen production system using a centrifugal acceleration field, a prototype rotary water electrolyser has been constructed. A number of design challenges, e.g. rotary electric connector with extremely low resistance and large current capability, were overcome. Extensive tests were performed and the variables covered included current density ranged from 2.3 to $22.5 \mathrm{kA} \mathrm{m}^{-2}$, centrifugal acceleration up to $70 \mathrm{~g}$, electrolyte concentration from $2.0 \mathrm{M}$ to $11.9 \mathrm{M} \mathrm{KOH}$, and temperature up to $254 \mathrm{~K}$ for a variety of electrode structures. Equivalent tests were also performed using a static cell in order to provide reference for comparison. Cell voltage traces were recorded and used to evaluate the inter-electrode gas disengagement performance. The test results showed that:

1. At normal cell operating conditions $(7.7 \mathrm{M} \mathrm{KOH}, \sim 348 \mathrm{~K})$ over $80 \%$ cell voltage reductions were achieved at an acceleration less than $16 \mathrm{~g}$ (corresponding to low rotational speed of 500 rpm of the rig) in the tested current density range.

2. Both static and rotary cell tests showed that an electrode made from multiple layers of nickel mesh reduced the cell voltage, presumably due the effective activated area of the electrode was increased.

3. The rotary cell voltage was about $0.25-0.5 \mathrm{~V}$ less than the equivalent static cell under similar operating conditions, depending on the current density;

4. Although the electrodes were without a catalysed coating, operated at a moderately high temperature at atmospheric pressure, the rotary cell voltages achieved were comparable with typical values of fully developed pressurised industrial cells.

5. It was found that the amplitude of the fluctuations of the cell voltage time trace is a good indicator for judging the performance of the gas disengagement in the electrolysis cell. In an industrial application this can be useful to monitor the electrolyer performance as it provides an indication that the optimised centrifugal acceleration in the electrolysis cell has been reached.

6. The results suggest a compact intensified electrolyer for hydrogen production is feasible by exploiting the centrifugal acceleration provided by rotation.

\section{Acknowledgements}

We wish to acknowledge the financial support of the Engineering and Physical Sciences Research Council and the in-kind support of Johnson Matthey Ltd for this study. 


\section{References}

1. Ramshaw C (1993) Heat Recovery Systems and CHP 13: 493

2. Burns JR, Jamil JN, Ramshaw C (2000) Chem Eng Sci 55: 2401

3. Liu HS, Lin CC, Wu SC, Hsu HW (1996) Ind Eng Chem Res 35: 3590

4. Roizard C, Mokrani F, Gall H, Midoux N (1993) Chem Eng Sci 48: 2599

5. Uddholm H (1991) Int. J. Heat Mass Transfer 34: 941

6. Armand B, Uddholm H, Vikstrom P (1990) Ind Eng Chem Res 29: 436

7. Munjal S, Dudukovic MP, Ramachandran P (1989) Chem Eng Sci 44: 2245

8. Munjal S, Dudukovic MP, Ramachandran P (1989) Chem Eng Sci 44: 2257

9. Lin CC, Liu WT (2006) J Ind Eng Chem (2006) 12: 455

10. Wang GQ, Xu ZC, Yu YL, Ji JB (2008) Chem Eng and Processing 47: 2131

11. Matsushima H, Nishida T, Konishi Y et al (2003) Electrochim Acta 48:4119

12. Kaneko H, Tanaka K, Iwasaki A et al (1993) Electrochim Acta 38: 729

13. Fleischmann M, Jansson R, Marshall R (1978) Electrochemical cells and methods of electrolysis. US Patent 4125439

14. Thomson E (1929) Electrolytic apparatus \& method of operation. US Patent 1701346

15. Hoover T (1964) Rotating electrolytic cell assembly. US Patent 3119759

16. Cheng H, Scott K, Ramshaw C (2002) J Appl Electrochem 32: 831

17. Cheng H, Scott K, Ramshaw C (2002) J Electrochem Soc 149: D172.

18. Ivy J (2004) Summary of electrolytic hydrogen production: milestone completion report. National Renewable Energy Laboratory. Available via www.nrel.gov/hydrogen/pdfs/36734.pdf. 


\section{List of figure captions}

\begin{tabular}{|c|c|}
\hline Figure1 & $\begin{array}{l}\text { Comparison of gas bubble evolution in alkaline electrolyte under (a) terrestrial gravity } \\
\text { and (b) microgravity conditions, at } 8 \mathrm{~s} \text { after starting water electrolysis using KOH } \\
\text { solution [11]. }\end{array}$ \\
\hline Figure 2 & The rotary electrolyser test rig \\
\hline Figure 3 & $\begin{array}{l}\text { Schematic of the rotary electrolyser cell (left) and arrangement of the actual electrode } \\
\text { (right) }\end{array}$ \\
\hline Figure 4 & $\begin{array}{l}\text { Electrode materials used for the experiments. (a) Nickel mesh and (b) Stainless steel } \\
\text { foam }\end{array}$ \\
\hline Figure 5 & Schematic of the static water electrolysis rig \\
\hline Figure 6 & $\begin{array}{l}\text { Cell voltage against current density for the static cell with electrodes comprised of } \\
\text { different materials. The conditions for the experiment were as follows: electrolyte, } 7.7 \mathrm{M} \\
\mathrm{KOH} \text { solution; bulk temperature, } 348 \mathrm{~K} \text {; inter-electrode space, } 2.0 \mathrm{~mm} \text {. Square solid dots } \\
\text { represent the experiment data for electrodes made of nickel mesh upon stainless steel } \\
\text { current feeding plate, and Triangular solid dots for electrodes made of stainless steel } \\
\text { current feeding plate only. }\end{array}$ \\
\hline Figure 7 & $\begin{array}{l}\text { Cell voltage versus current density for the static cell with electrodes comprised of } \\
\text { different number of nickel mesh layers. The conditions for the experiment were as } \\
\text { follows: electrolyte, } 7.7 \mathrm{M} \mathrm{KOH} \text { solution; bulk temperature, } 348 \mathrm{~K} \text {; inter-electrode space, } \\
2.0 \mathrm{~mm} \text {. Square solid dots represent the experiment data for electrodes made of one layer } \\
\text { of nickel mesh upon stainless steel plate, triangles for electrodes of two layers nickel } \\
\text { mesh upon stainless steel plate and round solid dots for electrodes of three layers nickel } \\
\text { mesh upon stainless steel plate. }\end{array}$ \\
\hline Figure 8 & $\begin{array}{l}\text { Cell voltage traces for the static cell with different inter-electrode spaces at a current } \\
\text { density of } 10 \mathrm{kA} \mathrm{m}^{-2} . \text { Heavy solid line represents the trace for the electrodes with inter- } \\
\text { electrode space of } 1.0 \mathrm{~mm} \text { and thin line for the electrodes with the space of } 3.0 \mathrm{~mm} \text {. }\end{array}$ \\
\hline Figure 9 & $\begin{array}{l}\text { Cell voltage against current density for the static cell at different concentrations of } \\
\text { electrolyte. The conditions for the experiment were as follows: bulk temperature, } 348 \mathrm{~K} \text {; } \\
\text { electrodes, three layers nickel mesh upon stainless steel plate. Square solid dots represent } \\
\text { the experiment data for electrolyte of } 2.0 \mathrm{M} \mathrm{KOH} \text { solution, round dots for } 7.7 \mathrm{M} \mathrm{KOH} \\
\text { solution and rhomboid dots for } 11.9 \mathrm{M} \mathrm{KOH} \text { solution. }\end{array}$ \\
\hline
\end{tabular}




\begin{tabular}{|c|c|}
\hline Figure 10 & $\begin{array}{l}\text { Cell voltage against centrifugal acceleration (in } g \text { ) for the rotary cell at different current } \\
\text { densities, with electrodes made of nickel mesh upon stainless steel plate. Different curves } \\
\text { correspond to data from different current densities of (a) } 22.5 \mathrm{kA} \mathrm{m}^{-2} \text {, (b) } 13.5 \mathrm{kA} \mathrm{m}^{-2}, \text { (c) } \\
9.0 \mathrm{kA} \mathrm{m}^{-2} \text {, (d) } 4.5 \mathrm{kA} \mathrm{m}^{-2} \text { and (e) } 2.3 \mathrm{kA} \mathrm{m}^{-2} .7 .7 \mathrm{M} \mathrm{KOH} \mathrm{solution} \mathrm{was} \mathrm{used;} \mathrm{solution} \\
\text { bulk temperature, } 344 \mathrm{~K} \text {. }\end{array}$ \\
\hline Figure 11 & $\begin{array}{l}\text { Cell voltage traces for the rotary cell at different current densities and rotation } \\
\text { accelerations (top) and their positions on the curves of cell voltage v.s. centrifugal } \\
\text { acceleration (bottom). Electrode material, nickel mesh upon stainless steel plate; } \\
\text { electrolyte, } 7.7 \mathrm{M} \mathrm{KOH} \text { solution; bulk temperature, } 344 \mathrm{~K} \text {. (a) current density of } 13.5 \mathrm{kA} \\
\mathrm{m}^{-2} \text { and acceleration of } 3.2 \mathrm{~g} \text {; (b) } 13.5 \mathrm{kA} \mathrm{m}^{-2} \text { and acceleration of } 41 \mathrm{~g} \text { and (c) } 2.3 \mathrm{kA} \mathrm{m}^{-2} \\
\text { and acceleration of } 3.2 \mathrm{~g} \text {. }\end{array}$ \\
\hline Figure 12 & $\begin{array}{l}\text { Cell voltage against centrifugal acceleration for the rotary cell with different electrode } \\
\text { structures. Line with solid triangles represents data from electrodes made of one layer of } \\
\text { nickel mesh upon a stainless steel plate; line with round dots represents electrodes of } \\
\text { three layers of nickel mesh upon a stainless steel plate. }\end{array}$ \\
\hline Figure 13 & $\begin{array}{l}\text { Cell voltage against centrifugal acceleration for the rotary cell with different temperature } \\
\text { of electrolyte. Line with crosses represents data from electrolyte at a bulk temperature of } \\
297 \mathrm{~K} \text {; line with dots represents data of } 354 \mathrm{~K} \text {. }\end{array}$ \\
\hline Figure 14 & $\begin{array}{l}\text { Cell voltage against centrifugal acceleration for the rotary cell with different } \\
\text { concentrations of KOH solutions. Line with square dots represent the experiment data for } \\
\text { electrolyte of } 2.0 \mathrm{M} \mathrm{KOH} \text { solution; line with round dots for } 7.7 \mathrm{M} \mathrm{KOH} \text { solution; and } \\
\text { line with rhomboid dots for } 11.9 \mathrm{M} \mathrm{KOH} \text { solution. Electrolyte solutions were at ambient } \\
\text { temperature. }\end{array}$ \\
\hline
\end{tabular}


$\mathrm{H}_{2}$

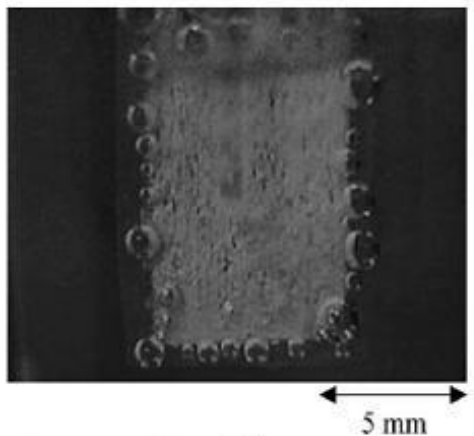

(a) Front View

$\mathrm{H}_{2}$

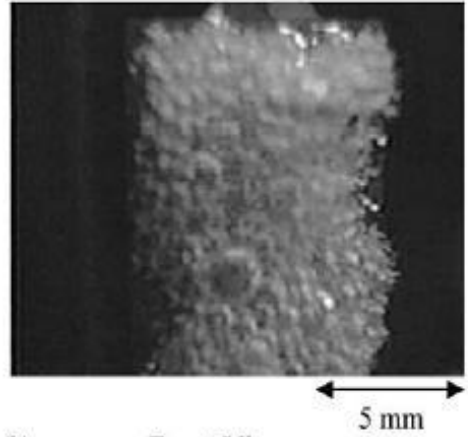

(b)

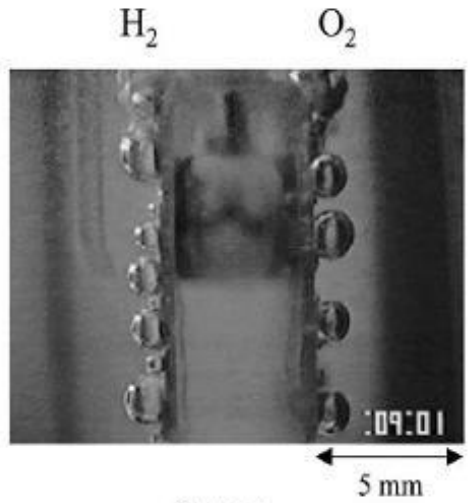

Side View

$\mathrm{H}_{2}$

$\mathrm{O}_{2}$

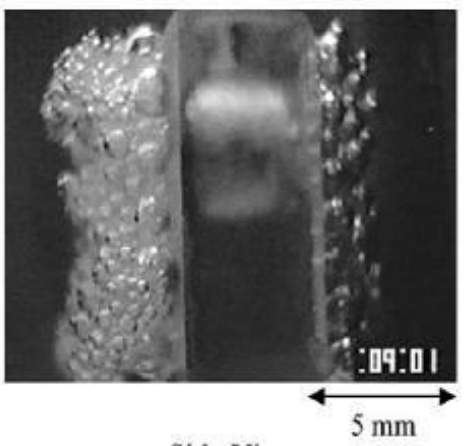

Side View

Figure 1 Comparison of gas bubble evolution in alkaline electrolyte under (a) terrestrial gravity and (b) microgravity conditions, at $8 \mathrm{~s}$ after starting water electrolysis using $\mathrm{KOH}$ solution [11].

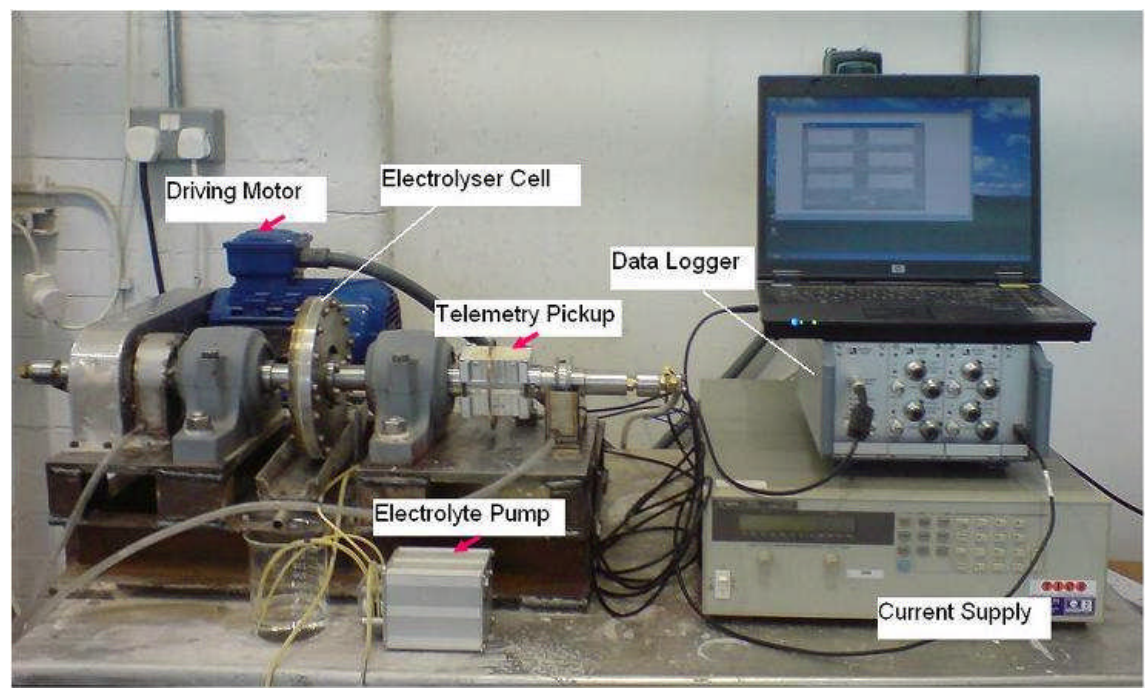

Figure 2 The rotary electrolyser test rig 

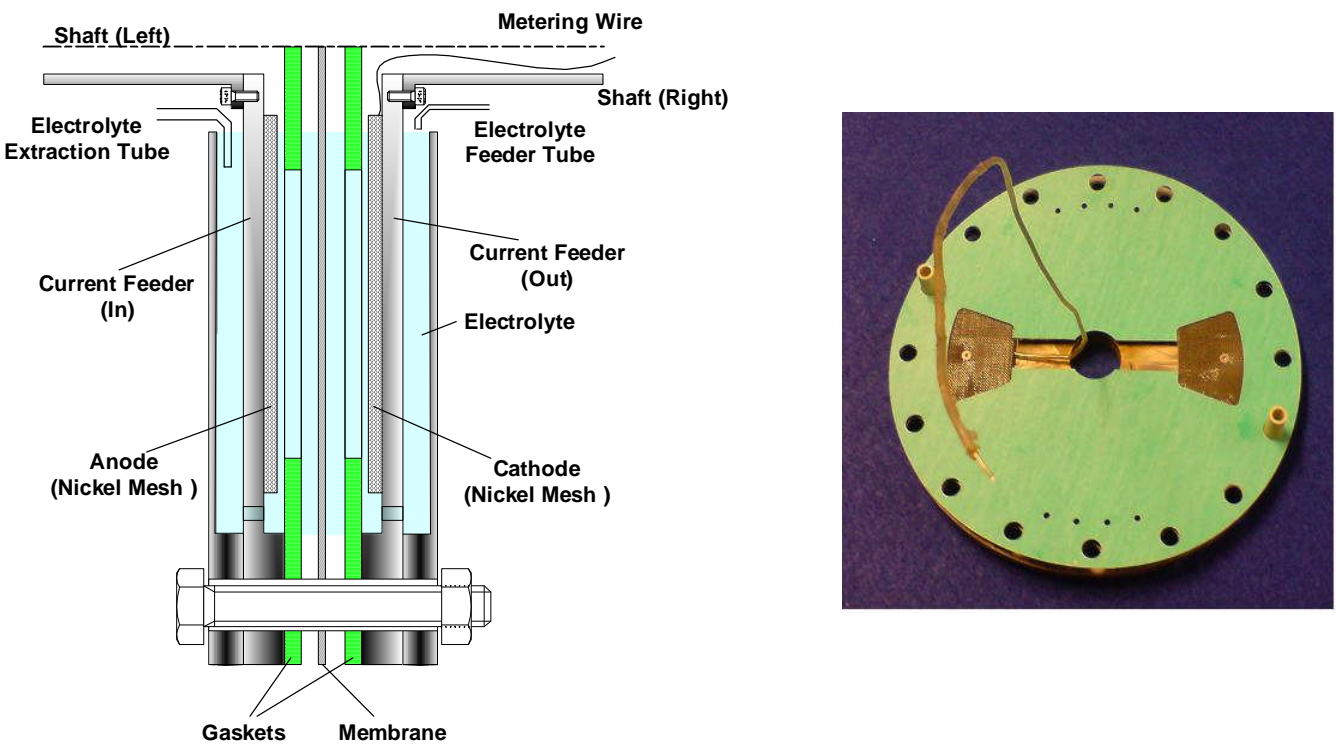

Figure 3 Schematic of the rotary electrolyser cell (left) and arrangement of the actual electrode (right)

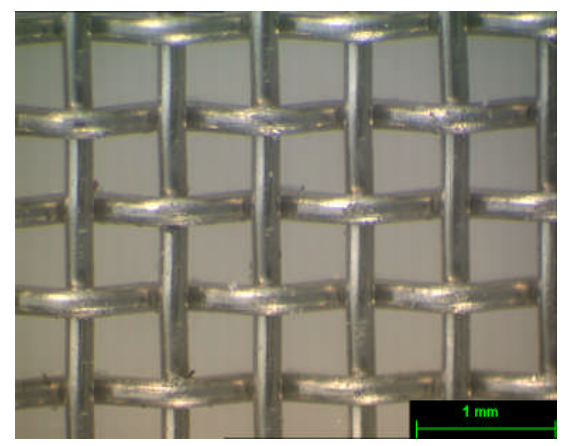

Figure 4 Nickel mesh as electrode material used for the experiments 


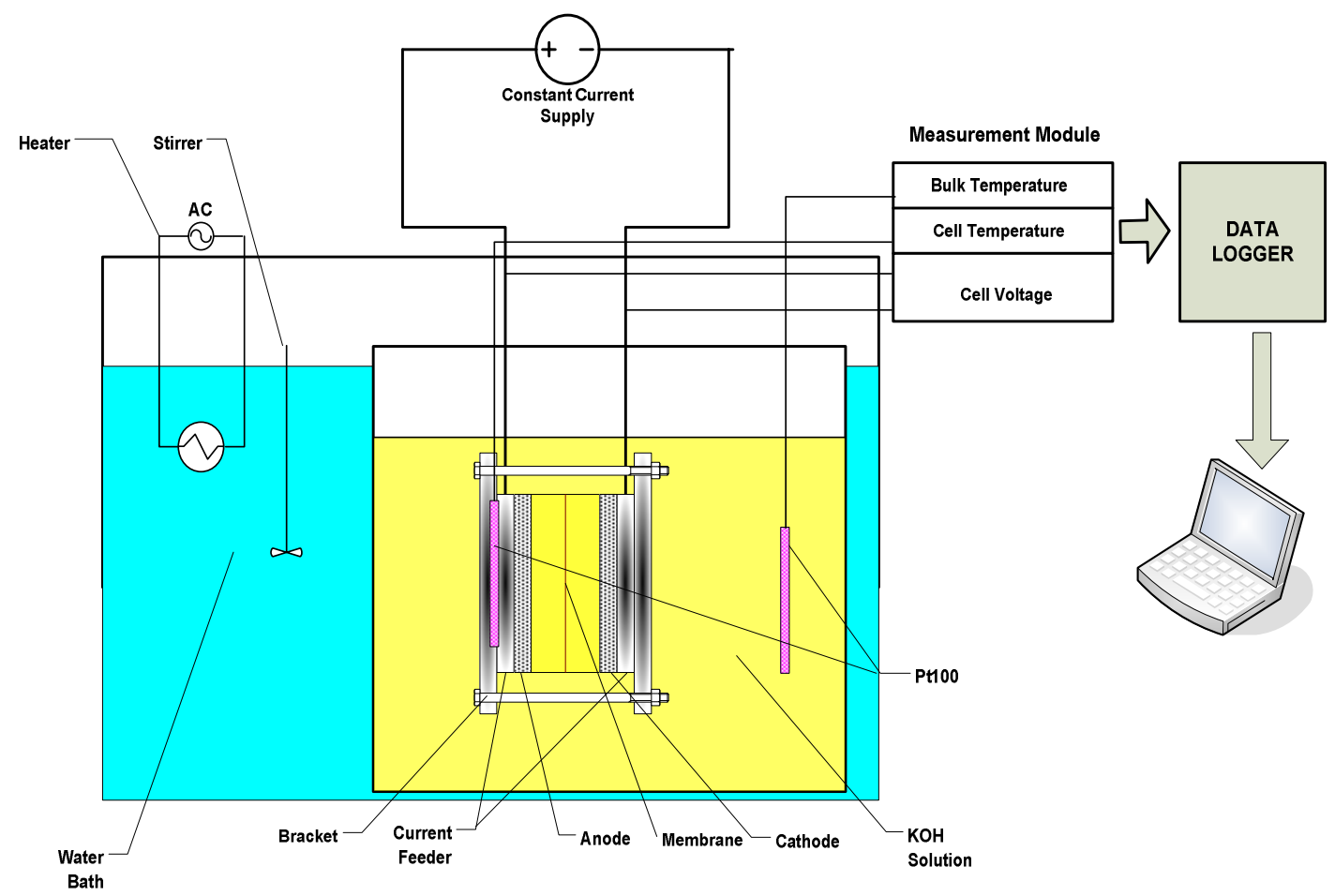

Figure 5 Schematic of the static water electrolysis rig

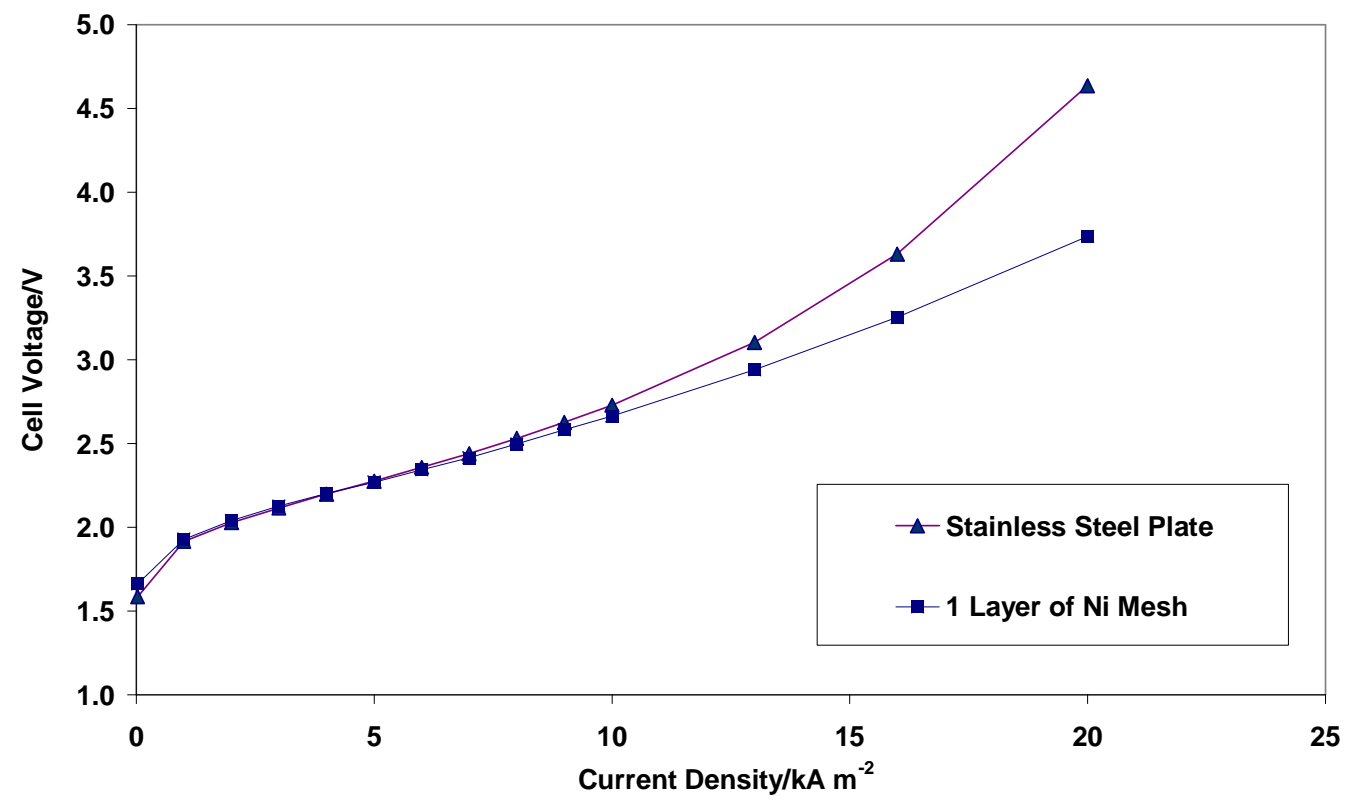

Figure 6 Cell voltage against current density for the static cell for different electrodes The conditions for the experiment were as follows: electrolyte, 7.7 M KOH solution; bulk temperature, $348 \mathrm{~K}$; interelectrode space, $2.0 \mathrm{~mm}$. Square solid dots represent the experiment data for electrodes made of nickel mesh upon stainless steel current feeding plate, and triangular solid dots for electrodes made of stainless steel current feeding plate only. 


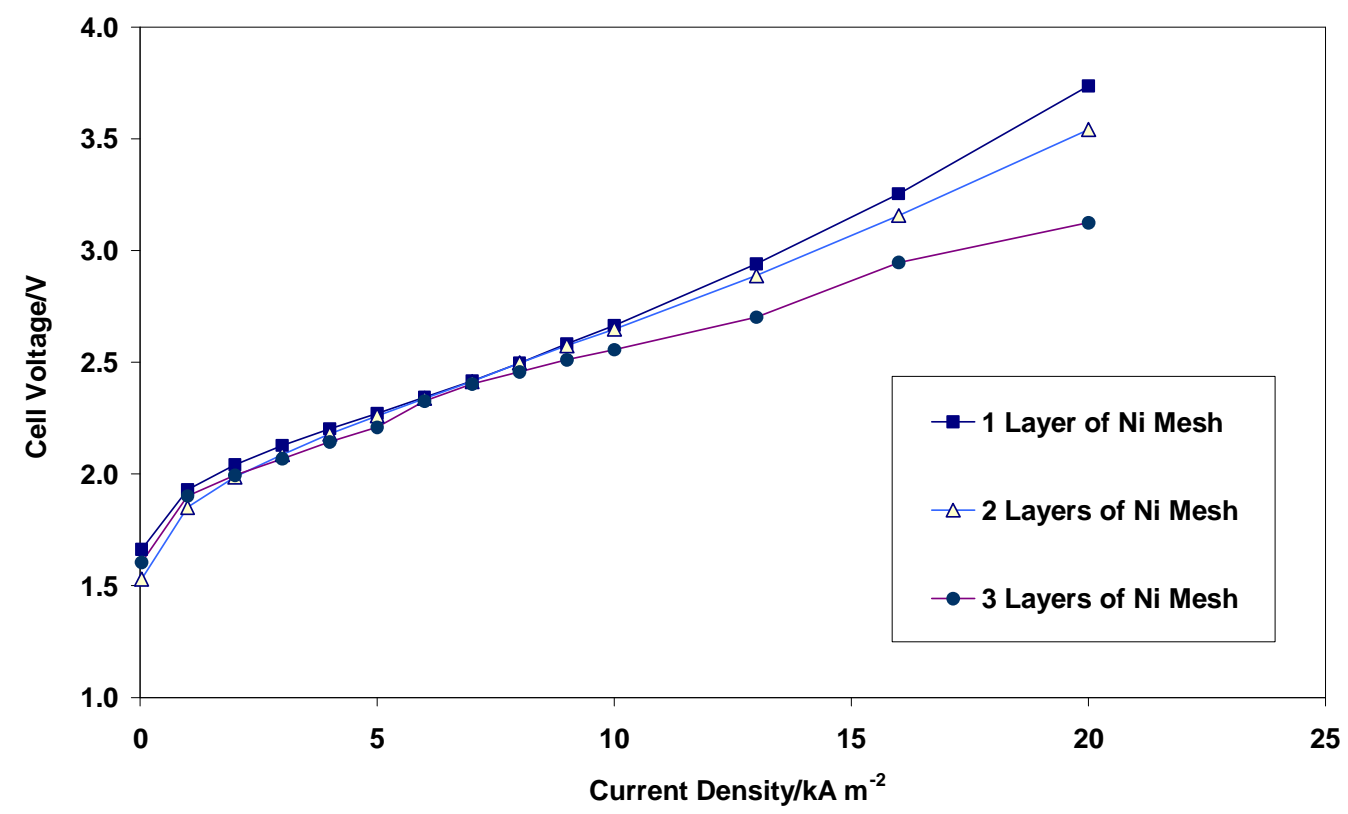

Figure 7 Cell voltage versus current density for the static cell with electrodes comprised of different number of nickel mesh layers. The conditions for the experiment were as follows: electrolyte, $7.7 \mathrm{M}$ $\mathrm{KOH}$ solution; bulk temperature, $348 \mathrm{~K}$; inter-electrode space, $2.0 \mathrm{~mm}$. Squared solid dots represent the experiment data for electrodes made of one layer of nickel mesh upon stainless steel plate, triangles for electrodes of two layers nickel mesh upon stainless steel plate and round solid dots for electrodes of three layers nickel mesh upon stainless steel plate.

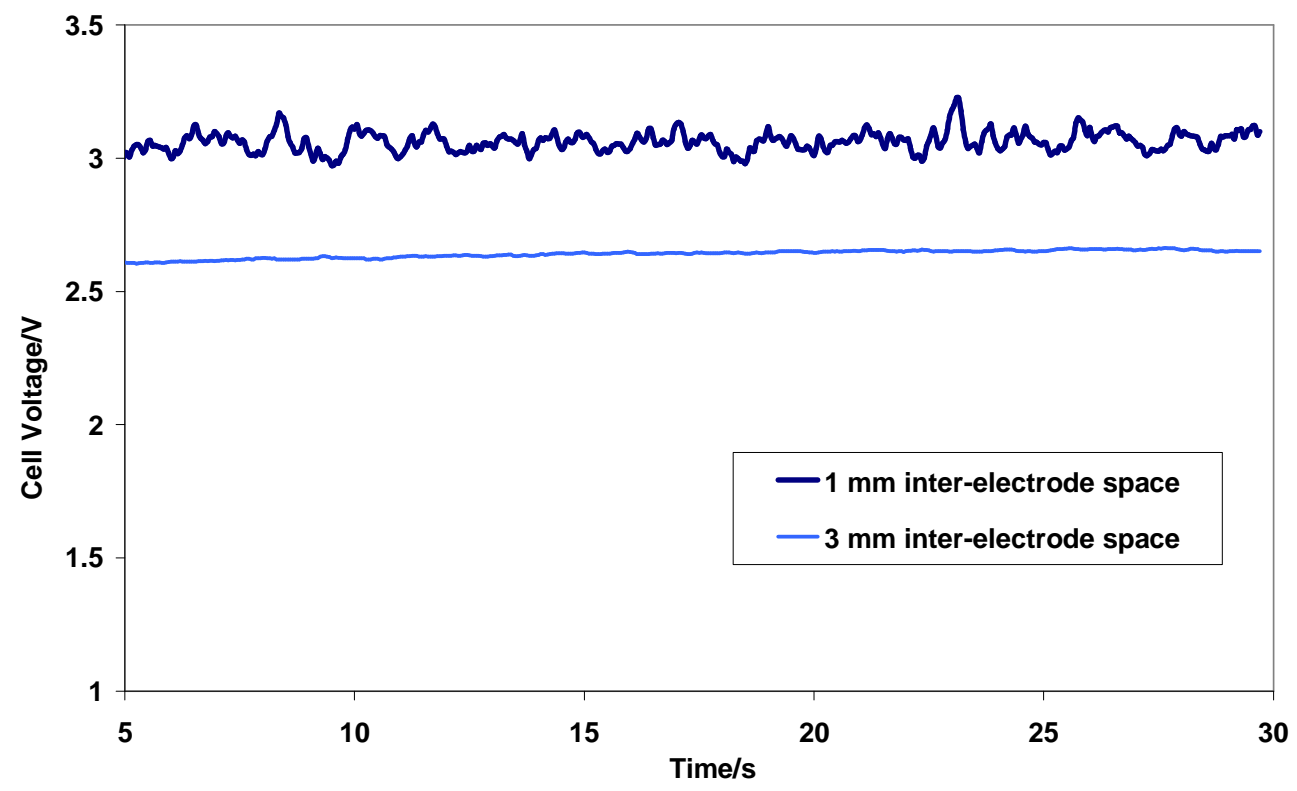

Figure 8 Cell voltage traces for the static cell with different inter-electrode spaces at a current density of $10 \mathrm{kA} \mathrm{m}^{-2}$. Heavy solid line represents the trace for the electrodes with inter-electrode space of 1.0 $\mathrm{mm}$ and thin line for the electrodes with the space of $3.0 \mathrm{~mm}$. 


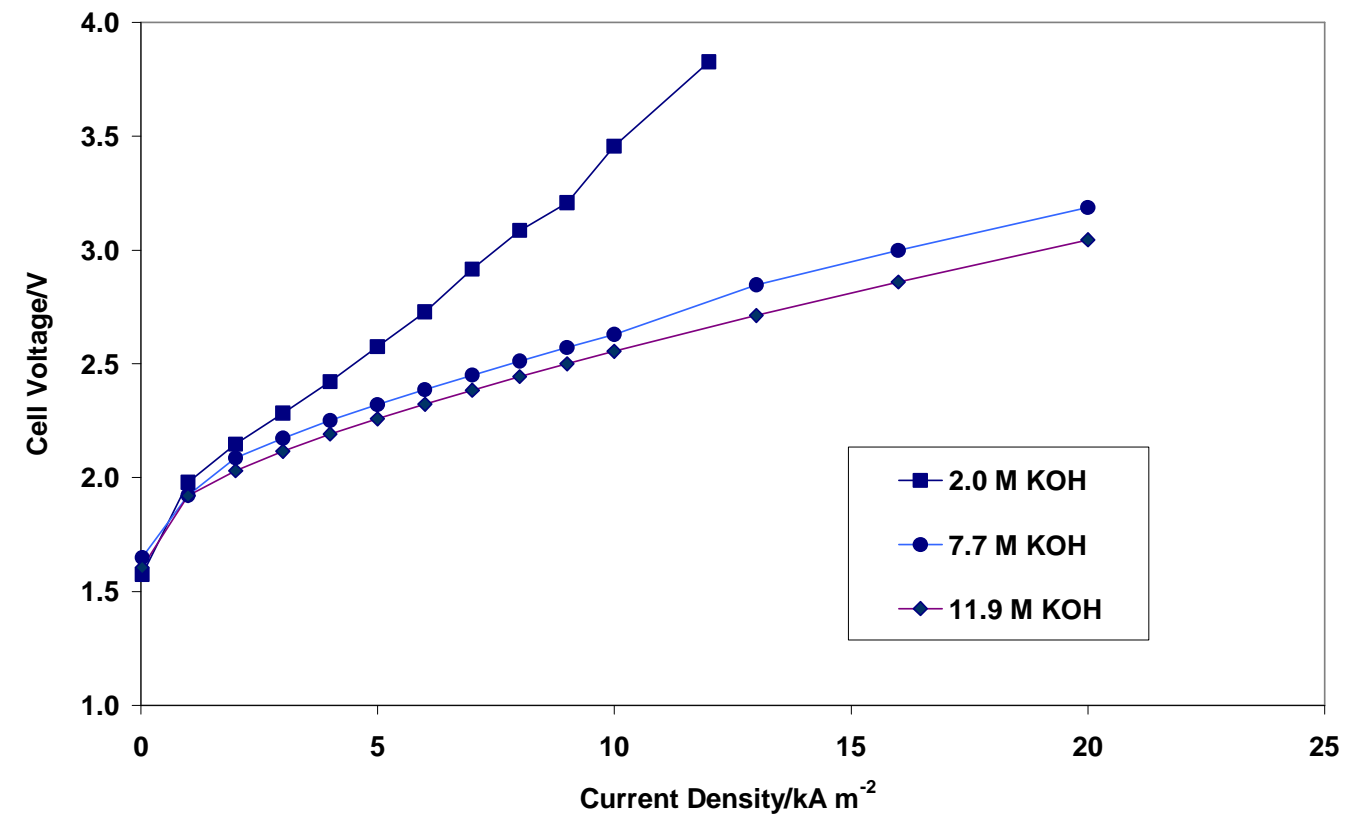

Figure 9 Cell voltage against current density for the static cell at different concentrations of electrolyte. The conditions for the experiment were as follows: bulk temperature, $348 \mathrm{~K}$; electrodes, three layers nickel mesh upon stainless steel plate. Squared solid dots represent the experiment data for electrolyte of 2.0 M KOH solution, round dots for 7.7 M KOH solution and rhomboid dots for $11.9 \mathrm{M} \mathrm{KOH}$ solution.

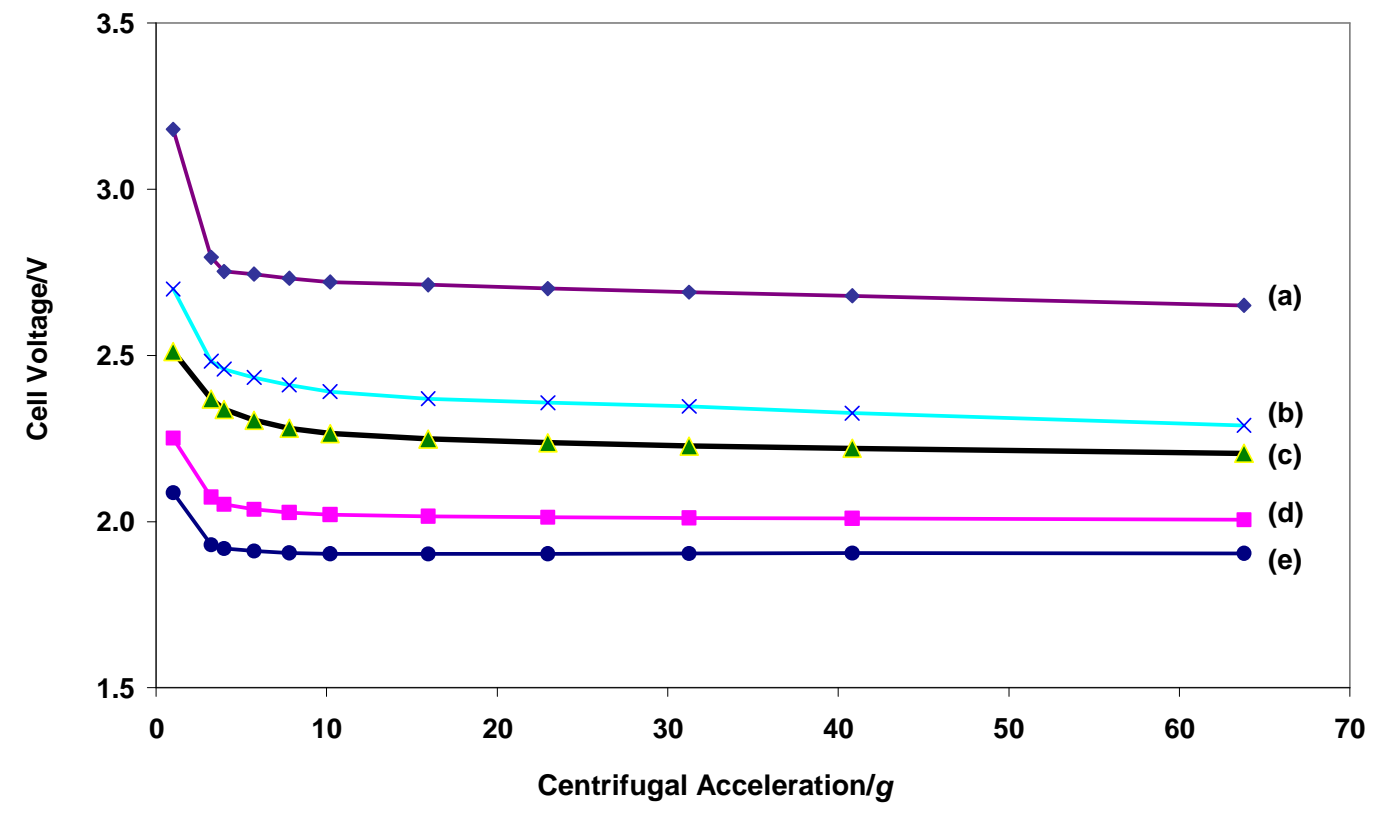

Figure 10 Cell voltage against centrifugal acceleration (in $g$ ) for the rotary cell at different current densities, with electrodes made of nickel mesh upon stainless steel plate. Different curves were corresponding to data from different current densities of (a) $22.5 \mathrm{kA} \mathrm{m}^{-2}$, (b) $13.5 \mathrm{kA} \mathrm{m}^{-2}$, (c) $9.0 \mathrm{kA} \mathrm{m}^{-}$ ${ }^{2}$, (d) $4.5 \mathrm{kA} \mathrm{m}^{-2}$ and (e) $2.3 \mathrm{kA} \mathrm{m}^{-2}$. $7.7 \mathrm{M} \mathrm{KOH}$ solution was used; solution bulk temperature, $344 \mathrm{~K}$. 

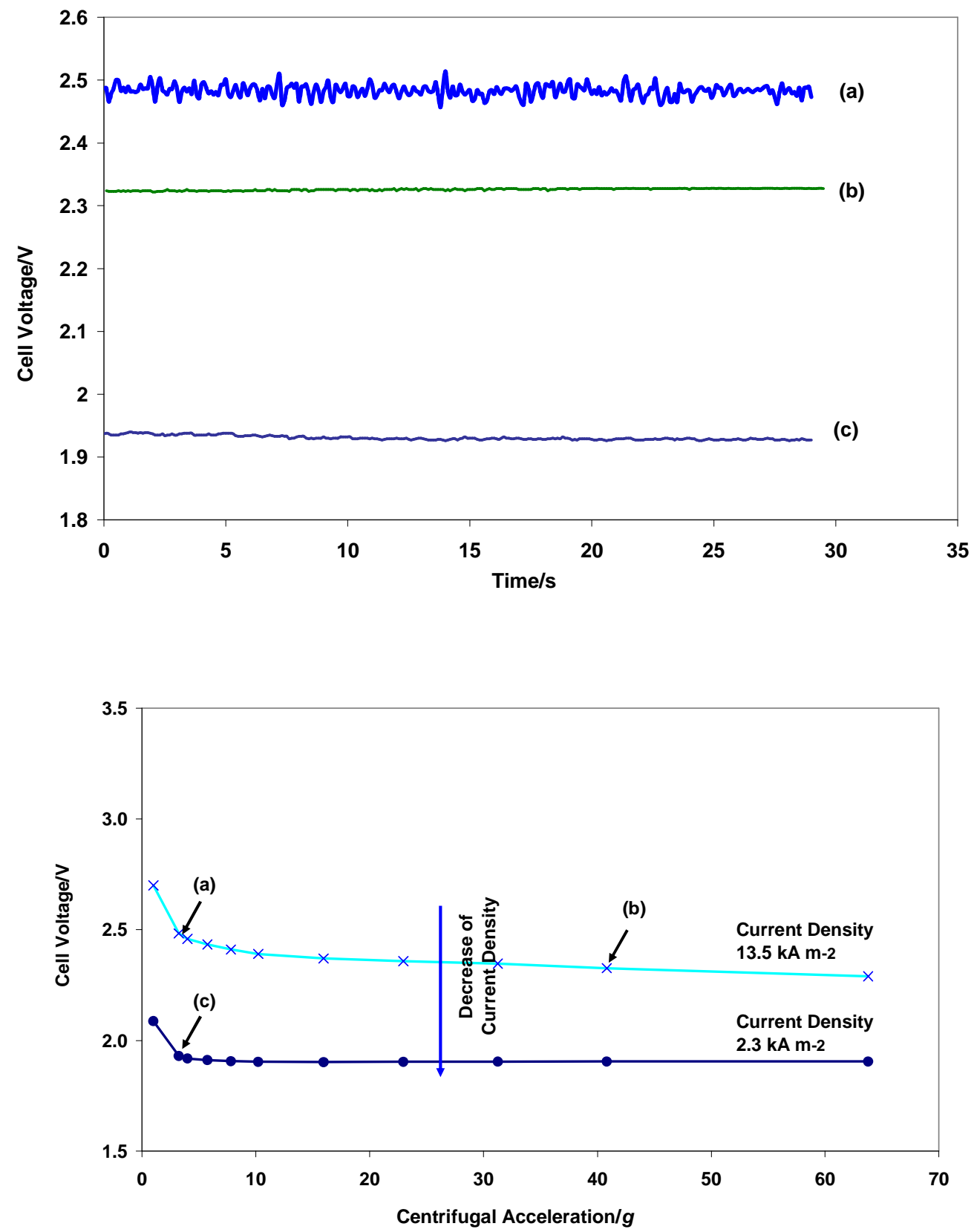

Figure 11 Cell voltage traces for the rotary cell at different current densities and rotation accelerations (top) and their positions on the curves of cell voltage v.s. centrifugal acceleration (bottom). Electrode material, nickel mesh upon stainless steel plate; electrolyte, 7.7 M KOH solution; bulk temperature, $344 \mathrm{~K}$. (a) current density of $13.5 \mathrm{kA} \mathrm{m}^{-2}$ and acceleration of $3.2 \mathrm{~g}$; (b) $13.5 \mathrm{kA} \mathrm{m}^{-2}$ and acceleration of $41 \mathrm{~g}$ and (c) $2.3 \mathrm{kA} \mathrm{m}^{-2}$ and acceleration of $3.2 \mathrm{~g}$. 


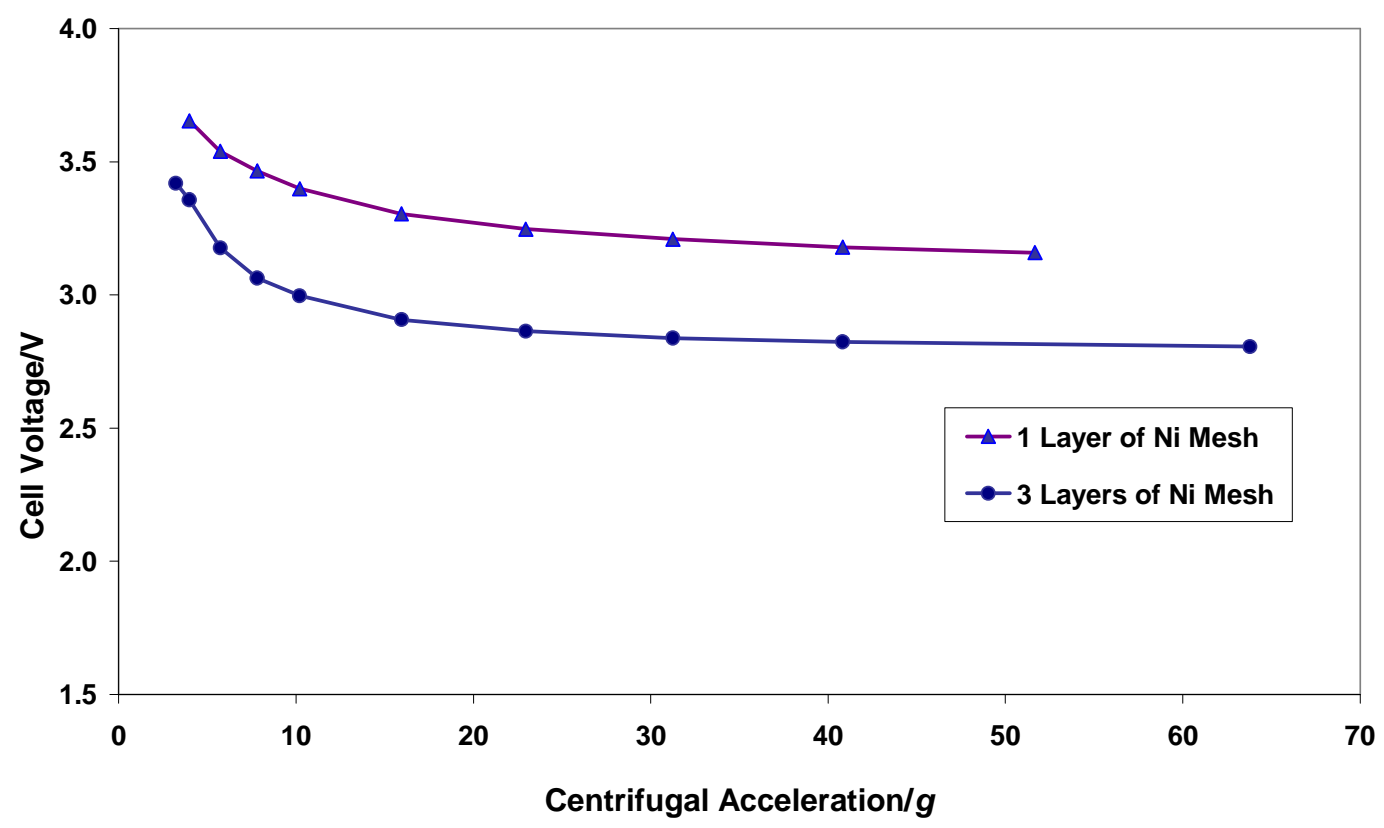

Figure 12 Cell voltage against centrifugal acceleration for the rotary cell with different electrode structures. Line with solid triangles represents data from electrodes made of one layer of nickel mesh upon a stainless steel plate; line with round dots represents electrodes of three layers of nickel mesh upon a stainless steel plate.

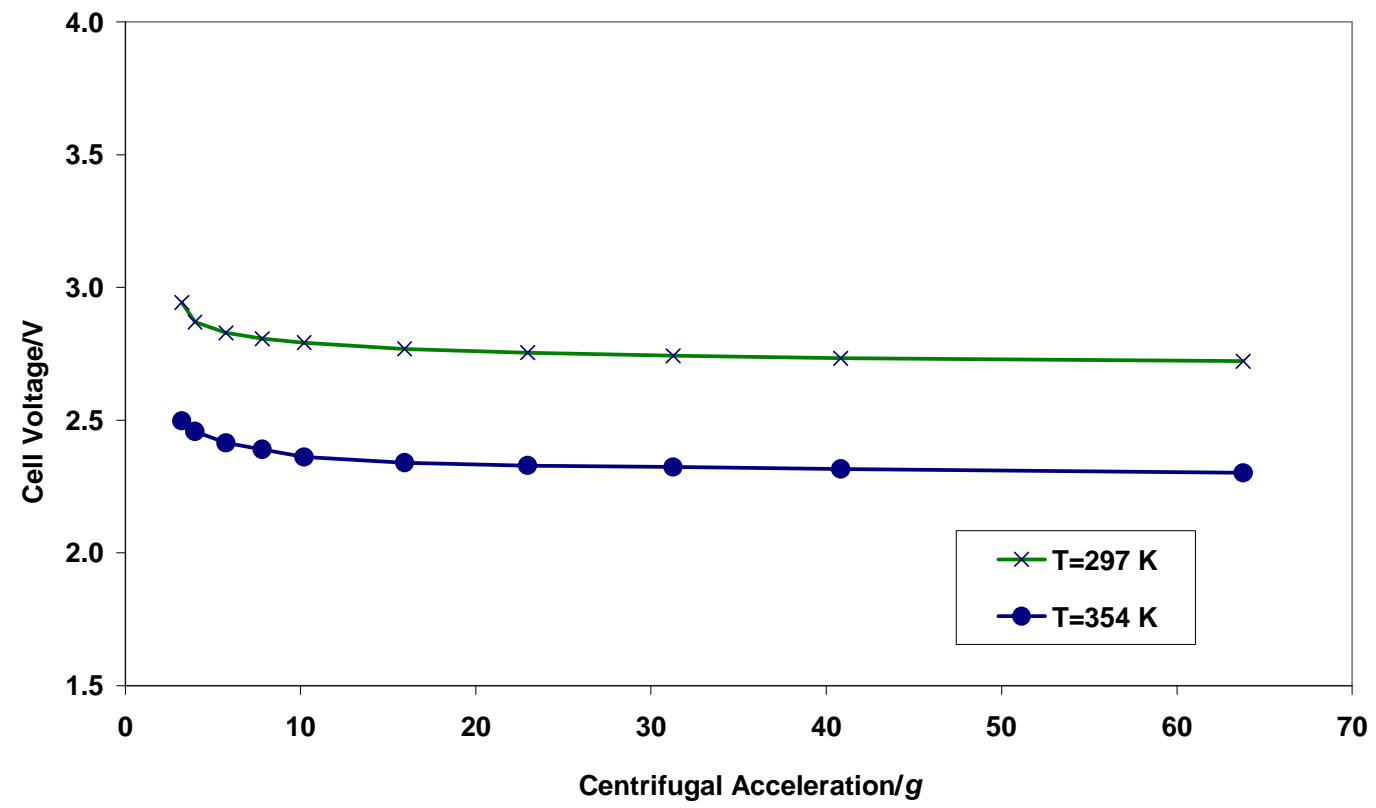

Figure 13 Cell voltage against centrifugal acceleration for the rotary cell with different temperature of electrolyte. Line with crosses represents data from electrolyte at a bulk temperature of $297 \mathrm{~K}$; line with dots represents data of $354 \mathrm{~K}$. 


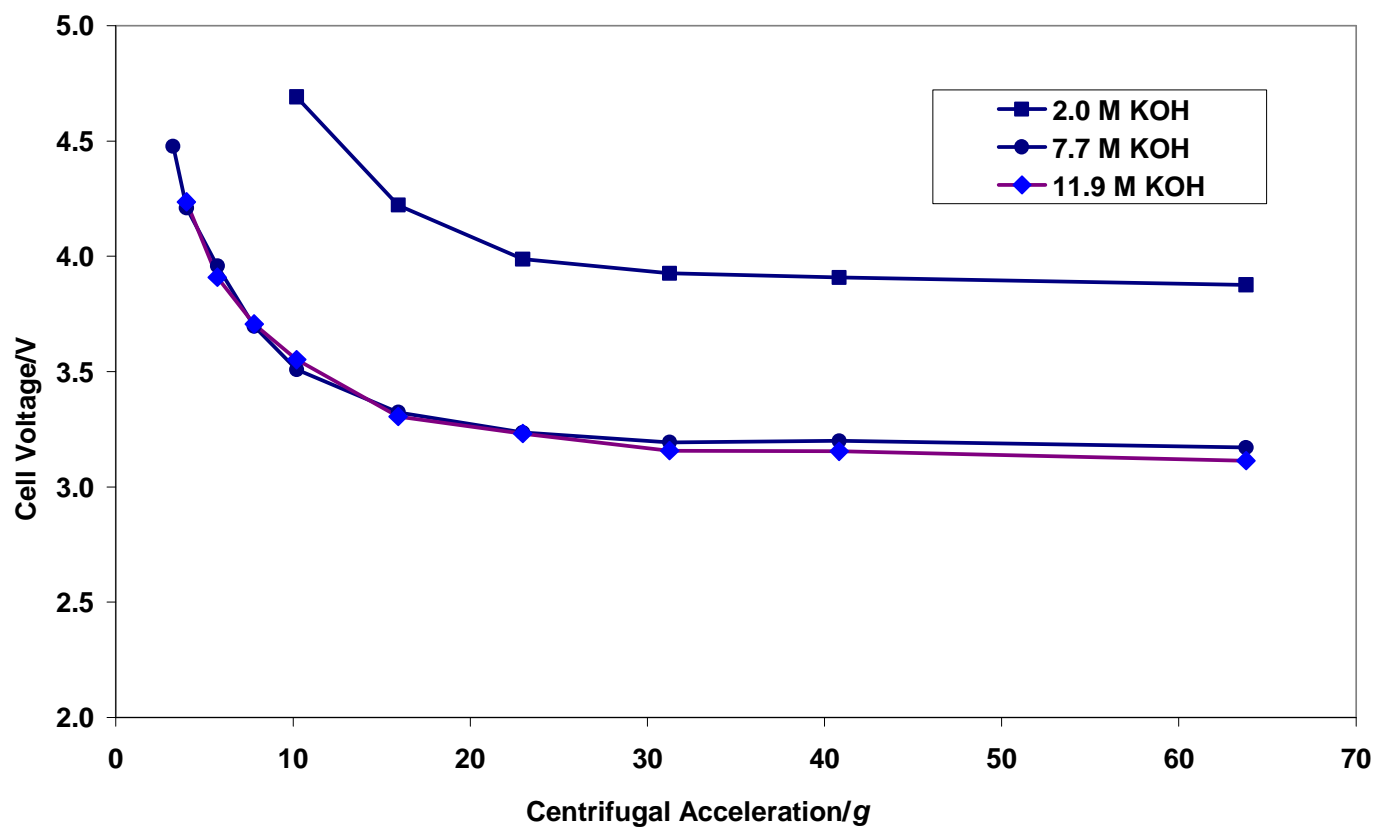

Figure 14 Cell voltage against centrifugal acceleration for the rotary cell with different concentrations of $\mathrm{KOH}$ solutions. Line with squared dots represent the experiment data for electrolyte of $2.0 \mathrm{M} \mathrm{KOH}$ solution; line with round dots for 7.7 M KOH solution; and line with rhomboid dots for 11.9 $\mathrm{M} \mathrm{KOH}$ solution. Electrolyte solutions were at ambient temperature. 